\title{
SERUM FREE TRIIODOTHYRONINE AND THYROID STIMULATING HORMONE LEVEL IN SEVERE PROTEIN ENERGY MALNOURISHED CHILDREN
}

\author{
SHAHJADI $\mathrm{S}^{1}$, KHAN AS ${ }^{2}$, AKHTER QS ${ }^{3}$, AKTER N ${ }^{4}$, HASAN SMMMA ${ }^{5}$, RAHMAN T ${ }^{6}$
}

\begin{abstract}
Context: A cross sectional study was carried out to observe the serum levels of $F T_{3}$ and TSH in severe Protein Energy Malnourished (PEM) children.

Methods: Total 70 subjects were selected, of whom 50 were severe PEM children (case group, $B$ ) and 20 were normal healthy children (control group, A). The case group $B$ also subdivided into $B_{1}$ (marasmus group) and $B_{2}$ (Kwashiorkor group).The subjects were taken from Dhaka Medical College Hospital, Shishu Hospital, GonoShastho Medical College Hospital

Result: In this study the mean $\pm(S D)$ of serum $F_{3}$ level of case were significantly lower $(p<.001)$ and the mean $\pm(S D)$ of serum TSH level of case were significantly higher $(p<.001)$ than that of control. But there were no significant difference between group $B_{1}$ and $B_{2}$.

Conclusion: In view of the above, it may be concluded that severe PEM causes decreased serum $\mathrm{FT}_{3}$ level and increased serum TSH level in children.
\end{abstract}

Key words: Protein Energy Malnutrition (PEM), marasmus, Kwashiorkor.

J Dhaka Med Coll. 2011; 20(2) : 174-177.

\section{Introduction}

Malnutrition is a nutrient deficiency state of protein, energy or micronutrients i.e vitamins and minerals. It is both a cause and consequence of ill health ${ }^{1}$. Protein Energy Malnutrition (PEM) constitutes a major pediatric problem in most developing countries. It affects the growth and development of infant's health. PEM is a syndrome in which all organs and tissues are involved. Deficiency of either caloric intake or protein diet or both are the causes of Protein Energy Malnutrition ${ }^{2}$.

Thyroid gland secretes two significant hormones, thyroxine and tri-iodothyronine, commonly called $\mathrm{T}_{4}$ and $\mathrm{T}_{3}$ respectively. Thyroid hormones are essential for normal growth and skeletal maturation. They potentiate the effect of growth hormone on the tissue. In hypothyroid children bone growth is slowed and epiphyseal closure is delayed. In hypothyroidism mental development is slow and the CSF protein level is elevated. Thyroid hormones have marked effects on brain development and its deficiency affects the cerebral cortex, basal ganglia and cochlea. Consequently, thyroid hormones deficiency during development causes mental retardation, motor rigidity and deaf- mutism ${ }^{3}$.

PEM occurs more in infants and young children at the age of weaning. Both males and females are affected by PEM. Nutritional deficiencies are occurred more among pre-school children. As a result, they cannot enter into primary education at a proper time 4 . In starvation, carbohydrate and fat are used as the source of energy. In malnutrition muscle breakdown occurs, giving rise to impaired immunity and increased susceptibility to illness.

1. Dr. Shorifa Shahjadi, Assistant Professor, Department of Physiology, MARKS Medical College, Dhaka.

2. Dr. Arif Salam Khan, Resident surgeon, Dhaka Medical College, Dhaka

3. Dr. Qazi Shamima Akhter, Head of the Department, Physiology, Dhaka Medical College, Dhaka

4. Dr. Nurjahan Akter, M Phil, Physiology

5. Dr. S.M.Md Mahid-Al-Hasan, M Phil, Pharmacology

6. Dr. Tahmina Rahman, Assistant Professor, Department of Physiology, Samorita Medical College, Dhaka.

Correspondence : Dr. Shorifa Shahjadi, Assistant Professor, Department of Physiology, MARKS Medical College, Dhaka. 
PEM can arise from primary or secondary causes. Primary PEM results from inadequate or poor quality food intake. Secondary PEM occurs from diseases that alter food intake or nutrient requirements, metabolism, or absorption. Infant and young children who lose $20 \%$ or more body weight is generally classified as severe PEM. People with this condition cannot eat normal quantity of meals. They have slow heart rates and low blood pressure and body temperatures ${ }^{1}$.

Secondary PEM symptoms range from mild to severe, and can alter the form or function of almost every organ in the body. The type and intensity of symptoms depend on the patient's prior nutritional status and on the nature of the underlying disease. Other symptoms of severe secondary PEM include baggy, wrinkled skin; constipation; dry, thin, brittle hair ; lethargy; pressure sores and other skin lesions.

Marasmus and kwashiorkor are the two main types of PEM. People who have kwashiorkor often have extremely thin arms and legs, but liver enlargement and ascites (abnormal accumulation of fluid) can distend the abdomen and hide weight loss. Hair may turn red or yellow. Anaemia, diarrhoea, and electrolyte disorders are common. The body's immune system is weakened, behavioral development is slow, and mental retardation may occur. Children may grow to normal height but are abnormally thin.

Kwashiorkor- like secondary PEM usually develops in patients who have been suffering from tissue- destroying infection or any other life- threatening illness. The onset is so sudden that body fat and muscle mass of the children having normal weight may not change. Severe marasmus is accompanied profound weakness. Since the body breaks down its own fats and muscles to be used as calories, children with this condition lose all their body fat and muscle strength. They acquire a skeletal appearance most noticeable in the hands and in the temporal muscle in front of and above each ear. Children with marasmus are small for their age. Since their immune systems are weakened, they suffer from frequent infections. Other symptoms include loss of appetite, diarrhoea, skin that is dry and baggy, sparse hair that is dull brown or reddish yellow, mental and behavioral retardation, low body temperature (hypothermia), and slow pulse and breathing rate $^{5}$.

Severe PEM affects physiology of the thyroid hormone, especially peripheral hormone metabolism ${ }^{6}$.

In short term Protein energy malnutrition, thyroid abnormalities are confined to the thyroid hormonal transport system . Long-term PEM induced hypothyroidism places children at risk for possible brain damage ${ }^{7}$.

In PEM carbohydrate and vitamin deficiency inhibit the liver microsomal enzyme for conversion of $\mathrm{T}_{4}$ to $\mathrm{T}_{3}$. This reduction in $\mathrm{T}_{3}$ level can be explained by impaired liver function in PEM children. Cortisol which is found to be elevated in the acute stages of PEM also prevents $\mathrm{T}_{3}$ generation from $\mathrm{T}_{4}$ by inhibiting the 5- deiodinase system. That is why lower $\mathrm{T}_{3}$ level is found among PEM children ${ }^{2}$.Serum TSH level increased due to decrease serum $\mathrm{FT}_{3}$ level. Thyroid hormones deficiency affects in all stages of life. Its deficiency causes physical and mental handicap and poor educability of children. Thyroid disorders is a public health problem not only in Bangladesh but also in many developing countries.

\section{Methods}

This cross sectional study was carried out in the Department of Physiology, Dhaka Medical College, Dhaka. For this purpose total 70 subjects were selected, of whom 50 were severe PEM children (case group, B) and 20 were normal healthy children (control group, A). The case group $B$ also subdivided into $B_{1}$ (marasmus group) and ) $\mathrm{B}_{2}$ (Kwashiorkor group).The subjects were taken from Dhaka Medical College Hospital, Shishu Hospital, GonoShastho Medical College Hospital. Mid -upper arm circumference, weight-for-height median (WHM), weight-for-height $\mathrm{z}$-score (WHZ), bipedal oedema (kwashiorkor), HB\%, were the criteria for selection of severe 
malnourished children Common anthropometric indicators of child malnutrition are combinations of body measurements and age, because the short-term response of a child's body to inadequate food intake is to slow down growth. This results in low height-for-age (stunting) and low weight-for-height (wasting). The indicators recommended for international use are: stunting, wasting and underweight (a measure of both stunting and wasting). To assess the level of malnutrition, a child's height and weight are compared with the NCHS/WHO reference curves of height-for-age, weight-for-age and weight-for-height. Child malnutrition must be stratified by level of severity (i.e. mild, moderate, severe) .Different degrees of malnutrition have different associated risks. According to $Z$ score, severe, moderate and mild are classified as- children who fall below $-3 \mathrm{SD}$, and in the intervals $-3 \mathrm{SD}$ to $<-2 \mathrm{SD}$, and $-2 \mathrm{SD}$ to $<-1 \mathrm{SD}$ from the median of the weight-for-age distribution for the child population. Permission was taken from the concerned departments \&authorities. Informed written consent was taken from all the study subjects after full explanation of nature and purpose of the study. All the subjects were explained about the aims and objectives of the study. The test procedure were briefed and demonstrated and written consent were taken before performing the test. With all aseptic precautions $5 \mathrm{ml}$ venous blood was drawn from the antecubital vein in a disposable syringe and then blood was immediately transferred to a dry clean test tube and allowed to clot. After clot formation, serum was separated by centrifuging the blood at 3000 rpm for 5 minutes. Serum was kept in micro centrifuge tube after labeling and was preserved at $-20^{\circ} \mathrm{C}$ until analysis. Estimation of serum $\mathrm{FT}_{3}$ levels of study subjects were done by RIA and TSH levels were done by IRMA at Center for Nuclear Medicine \& Ultrasound, DMCH campus, Dhaka. After the collection of data these were checked, verified, edited for consistency to reduce error. Analysis of data were done with the help computer by SPSS program version of 12.0 software facilities. Significance test were done by Student's unpaired " $t$ " test.

\section{Results}

Results were expressed as mean \pm SD ( Standard deviation ). The statistical significance of difference between the groups were evaluated by using Student's unpaired 't' test in case and control groups and by ANOVA test in case of subgroups (case).

\section{Table-I}

Mean $\pm S D$ of serum $\mathrm{FT}_{3}$ and TSH level in study and control group

\begin{tabular}{lccc}
\hline Group & $\begin{array}{c}\text { Number of } \\
\text { subject }\end{array}$ & $\begin{array}{c}\text { Serum free } \mathrm{T}_{3} \\
(\mathrm{p} \mathrm{mol} / \mathrm{L})\end{array}$ & $\begin{array}{c}\text { Serum TSH } \\
(\mathrm{mIu} / \mathrm{L})\end{array}$ \\
\hline $\mathrm{A}$ & 20 & $6.44 \pm .76$ & $2.97 \pm .21$ \\
& & $(5.14-7.62)$ & $(2.50-3.23)$ \\
$\mathrm{B}_{1}$ & 25 & $3.16 \pm .30$ & $4.98 \pm .32$ \\
& & $(2.59-3.88)$ & $(4.13-5.43)$ \\
$\mathrm{B}_{2}$ & 25 & $3.10 \pm .26$ & $5.02 \pm .29$ \\
& & $(2.78-3.88)$ & $(4.10-5.60)$ \\
\hline
\end{tabular}

Statistical analysis

\begin{tabular}{lccc}
\hline Group & DF & $\mathrm{t} \& \mathrm{p}$ & $\mathrm{t} \& \mathrm{p}$ \\
& & Serum $\mathrm{FT}_{3}$ level & Serum TSH level \\
\hline 'A vs B ${ }_{1}$ & 43 & $4.04 .0011^{(* *)}$ & $\left.5.29 .0011^{(* *}\right)$ \\
A vs B $_{2}$ & 43 & $\left.4.20 .001{ }^{(* *}\right)$ & $\left.5.73 .0011^{* * *}\right)$ \\
$\mathrm{B}_{1}$ vs B $_{2}$ & 48 & $.077 \mathrm{NS}$ & $.10 \mathrm{NS}$ \\
\hline
\end{tabular}

The results were expressed as Mean \pm SD. Unpaired Student's ' $t$ ' test is performed to compare between groups. The test of significance was done and $p$ values $<0.05$ was accepted as significance level.

A normal healthy children $* * *=p<0.001$

$B_{1}$ Marasmus group NS=Not significant

$\mathrm{B}_{2}$ Kwashiorkor group $\quad \mathrm{DF}=$ Degree of Freedom

\section{Discussion}

Results are shown in Table-I

The mean $\pm \mathrm{SD}$ serum $\mathrm{FT}_{3}$ levels were $6.46 \pm$ $0.76 \mathrm{pmol} / \mathrm{L} 3.16 \pm 0.30 \mathrm{pmol} / \mathrm{L}, 3.10 \pm 0.26$ $\mathrm{pmol} / \mathrm{L}$ in group $\mathrm{A}, \mathrm{B}_{1} \& \mathrm{~B}_{2}$ respectively. In this study the mean \pm (SD) levels of serum $\mathrm{FT}_{3}$ of case and control were within normal limit but mean $\pm(\mathrm{SD})$ levels of $\mathrm{FT}_{3}$ of case were lower than control $8,9,10,11,12$. Decrease in serum $\mathrm{FT}_{3}$ level was due to carbohydrate and vitamin deficiency which inhibit the 
liver microsomal enzyme for conversion of $\mathrm{T}_{4}$ to $\mathrm{T}_{3}$. Cortisol which is found to be elevated in the acute stages of PEM also prevents $T_{3}$ generation from $\mathrm{T}_{4}$ by inhibiting the 5deiodinase system ${ }^{2}$ Decreased in serum $\mathrm{FT}_{3}$ concentration were due to low intake of amino acids by severe PEM children ${ }^{6}$.

The mean \pm SD serum TSH levels were $2.97 \pm$ $0.21 \mathrm{mIu} / \mathrm{L} 4.98 \pm 0.32 \mathrm{mIu} / \mathrm{L}, 5.02 \pm 0.29$ $\mathrm{mIu} / \mathrm{L}$ in group $\mathrm{A}, \mathrm{B}_{1} \& \mathrm{~B}_{2}$ respectively. The mean \pm SD of serum TSH levels in group $B_{1} \&$ $B_{2}$ were significantly higher $(p<0.001)$ than that of control $8,9,10,11,12$, But there was no statistically significant difference between group $\mathrm{B}_{1}$ and $\mathrm{B}_{2}$. Increased level of TSH was caused by decreased serum $\mathrm{FT}_{3}$ levels in the blood $^{13 .}$

\section{Conclusion}

It may be concluded that severe PEM causes decreased serum $\mathrm{FT}_{3}$ level and increased serum TSH level in children.

\section{References:}

1. Kasper DL. Braunwald E, Fauci AS, Amson JL, Hausu SL, eds. Harrison's principle of internal medicine. $17^{\text {th }}$ ed. Mc Graw- Hill; 2008. p.456.

2. Aziz A, Yakout E, Nagwa A, Wafaa $M K$ et al . Study of some Hormones in Protein Energy Malnutrition .Med J Cairo Univ. 1994; 62: 143-49.

3. Ganong WF. Review of Medical Physiology. 22 $2^{\text {nd }}$ ed. USA : Prentice Hall International, Inc; 2005. p. 317-32.
4. Pollitt E, Lewis N. Nutritional requirement. Human Nutrition Center, School of Public Health, University of Texas, Houston, Texas. Nature Genetics 2008.

5. Haggerty M. Protein Energy Maqlnutrition : Causes and Symptoms. Medical Encyclopedia. 2009: 1,2 .

6. Turkay, Kus, Gokalp, Baskin, Onal .Effects of Protein Energy Malnutrition on circulating Thyroid Hormones. Indian Pediatrics. 1995 ; 32 : 193-96.

7. Ingenbleek Y.Thyroid dysfunction in protein calorie malnutrition. IBIDS. 1986; 44(8): 253-63.

8. Amanda L. Endocrinology of the neonate. British $\mathrm{J}$ of Hospital Medicine. 1995; 54: 207-11.

9. Chopra IJ, Smith SR. Circulatory Thyroid hormones and thyrotropin in adult patients with PCM. J of Clin Endocrinol and Metab. $1975 ; 40: 221-27$.

10. Hatemi N, Haktun M, Genca E, Cuma T . Thyroid function in Protein Energy Malnutrition. The Turkish J of Pediatrics. 1982; 24 ( 1) : 29-34.

11. Onuora C, Maharajan G, Singh A. Thyroid Status in various degrees of Protein Calorie Malnutrition in children. Clin Endocrinol. 1983; 18: 87-93.

12. John W, Kaeren J, Aletta M, Drimmelen M et al. Thyroid hormone and carrier protein interrelationships in children recovering from Kwashiorkor. The American $J$ of clin nutrition.1986; 43: 406- 13.

13. Kumar S, Nadkarni J, Dwivedi R. Thyroid Hormone Status in Malnourished Children. Indian Pediatrics. 2009; $46: 263-64$. 